\title{
LEPROMIN NOT INACTIVATED BY LEPROMATOUS SERUM
}

DHARMENDRA, M.B.B.S., D.B.

and

N. Mukerjee, M.B.B.S., D.T.M., D.P.H.

Leprosy Department, School of Tropical Medicine, Calcutta, India. INTRODUCTION

In his interesting paper on 'The Significance of Antibody in the Pathogenesis of Leprosy," Ridley (I954) reported experiments which seemed to indicate "that in many lepromatous sera there is present an antibody which reacts with lepromin to fix complement; and that. some lepromatous sera are capable of neutralising 
lepromin so that a mixture of the two does not elicit a response in the skin of tuberculoid patients."

Regarding the presence of lepromin complement fixing antibody it will suffice to say that sera from lepromatous cases have long been known to fix complement in presence of antigen prepared from a variety of acid-fast bacilli including the tubercle bacillus. This property of the lepromatous serum is therefore not likely to be due to the presence of a specific lepromin complement fixing antibody.

His finding regarding the inactivation of lepromin by incubation with lepromatous serum is a very interesting one, and if confirmed, would satisfactorily explain the negative reaction to lepromin in lepromatous cases. According to Ridley a negative reaction in such cases is caused by the neutralisation of the injected lepromin by a circulating antibody so that the antigen is not available for reaction with fixed antibody of the tissues to produce a positive reaction. In view of the important bearing that it may have on the matter, attempts were made to repeat Ridley's work regarding the inactivation of lepromin by lepromatous serum, and the results are reported herein.

\section{Methods AND Material}

In the work reported here sera from three active and advanced cases of leprosy of lepromatous type were used (designated in the tables as $\mathrm{A}, \mathrm{B}$ and $\mathrm{C}$ ). The sera were freshly drawn and were not inactivated by heat. Following the method used by Ridley, mixture of equal parts of serum and lepromin was incubated at $37^{\circ} \mathrm{C}$. for half an hour and then put in the refrigerator for about 24 hours before being used for the test. As controls were used mixtures of: (i) lepromin and tuberculoid serum; (ii) lepromin and physiological saline; (iii) lepromatous serum and saline; (iv) tuberculoid serum and saline; all the controls were prepared and incubated in the same way as the mixtures of lepromin and lenromatous serum.

As antigens two different preparations were used-the refined antigen prepared by the chloroform method and designated here as Dharmendra's antigen; and Mitsuda's antigen prepared by Wade's method and designated here as Wade's antigen.

For the test a total number of 24 patients of the tuberculoid type were used, all with thick, raised, bacteriologically negative lesions, i.e. persons who were expected to produce well-marked early and late reactions to lepromin. 
The patients were divided into 4 groups of 6 each. Each group was injected with a mixture of lepromin and lepromatous serum, together with 2 or 3 control mixtures, as indicated later. These injections were given intradermally into the arms of the patients. Early results ( 24 to 48 hours) were read in all the 4 groups, while late results up to 5 weeks were read in 2 groups.

\section{RESULTS}

The results in the 4 groups of cases with various mixtures are included in the accompanying tables and are summarised below:-

The results in Groups $I$ and II can be taken together since the only difference between the two groups is in the lepromin used, Dharmendra's antigen in one case (Group I) and Wade's antigen in the other (Group II). Serum from the same lepromatous case (A) was used for mixing with the antigens, and all other conditions were also similar. As controls were used the mixture of the antigen with: (i) physiological saline, and (ii) serum from a tuberculoid case. Both early and late reactions were read.

Regarding the early reaction, it may be said that in none* of the cases and with neither of the antigens used was early reaction less marked with the antigen mixed with lepromatous serum than with the other two preparations. On the other hand, in all the cases it was more marked with this particular preparation than with the other two preparations.

The late reaction, as was to be expected, was weaker with the refined antigen (D) than with the crude antigen (W). However, when the different preparations of the refined antigen are compared, it will be noted that the lepromin-lepromatous serum mixture has always given a little stronger reaction than the other two preparations. As compared with the refined antigen, the crude antigen (W) gave a stronger late reaction, and in this case there was not much difference in reaction to the 3 preparations, all of them giving reactions of about the same strength.

The results in Groups III and IV can be considered together as the two groups differ only in respect of the source of the lepromatous serum (from patient B in Group III and patient C in Group IV), and the dose of the various preparations (o.I c.c. in Group III, and 0.2 c.c. in Group IV). Only the refined antigen was used, and only early readings ( 24 to 48 hours) were taken. As controls to the lepromin-lepromatous serum mixture were used

\footnotetext{
* In one case with one of the antigens (IV) the reaction at 24 hours was slightly more markid with the antigen-saline mixture than with the antigcn-lppromatous serum mixture, but at 48 hours the reaction to the latter mixture was greater. In all other cases the reaction to the antigen-lepromatous serum mixture was greater at both the 24 and 48 hours readings.
} 
equal amounts of mixture of saline with: (i) lepromin, (ii) lepromatous serum, and (iii) tuberculoid serum.

A perusal of the results will show that as in the previous two groups the early reactions to the lepromin-lepromatous serum mixture were in no case less marked, but on the other hand were almost always more marked than those with lepromin-saline mixture. As was to be expected, the mixture of lepromatous and tuberculoid sera with saline generally gave negative results. However, one of the lepromatous sera gave rise to doubtful reaction in 2 cases and a definite but weak positive reaction in another case. Reaction with this serum (C) in the other cases and with the second serum (B) in all the 6 cases were negative. A similar reaction was seen in I of the I2 cases with the serum from a tuberculoid case. It is difficult to say anything about the significance of these reactions to the serum. It may, however, be said that it is not likely that these slight reactions were caused by any contaminating organism, since after incubation and storage in the refrigerator there was no gross turbidity seen in the serum-saline mixtures, nor did smears from them show any contamination.

\section{Discussion}

The findings reported here do not lend support to those of Ridley regarding the neutralisation of lepromin after it has been mixed and incubated with serum from a lepromatous case. Sera from 3 lepromatous cases were included in the study under report and 24 cases of tuberculoid type were tested with intradermal injections of mixtures of lepromin with these sera alone with some other mixtures similarly prepared and incubated. In none of the 24 cases was the addition of lepromatous serum to lepromin found to abolish or reduce the actiivty of lepromin. On the other hand, it was found to increase the activity since reaction to the lepromin-lepromatous serum mixture was almost always stronger than that to an equal amount of lepromin-saline mixture prepared and treated in an identical way.

In addition to the early reaction, late reactions (not reported on by Ridley) were observed in I 2 of the 24 patients. As in the case of early reaction, the addition of lepromatous serum to lepromin did not inhibit the late reactions also.

The hypothesis advanced by Ridley regarding the cause of negative lepromin reaction in lepromatous cases therefore cannot be upheld. According to his hypothesis the negative reaction to lepromin in such cases is caused by the presence of circulating antibody which neutralises the antigen before it can reach and react 
with the fixed antibody in the tissues. If confirmed this would have provided a plausible explanation for the little understood negative reaction to lepromin in lepromatous cases.

It has been stated above that the lepromin-lepromatous serum mixture, far from giving weaker reactions, gave stronger reactions than mixtures of lepromin with saline or tuberculoid serum. The reason for this is not clear. It may have been caused by the fact that lepromatous serum diffuses less rapidly from the site of injection thereby resulting in more marked induration which is maintained for a longer period. However, this is only a surmise. injection of lepromatous and tuberculoid sera (mixed with saline) did not provide any clear-cut evidence on this point, although they provide some indication to this effect.

\section{SUMMARY}

The addition of lepromatous serum to lepromin was not found to neutralise or reduce its strength as judged by the reaction produced by intradermal injection of the mixture in cases of leprosy of tuberculoid type. The findings of Ridley in this connection are therefore not confirmed.

In view of these results Ridley's explanation regarding the cause of a negative lepromin reaction in lepromatous cases cannot be supported and does not appear to be correct.

\section{REFERENCE}

Ridley, D. S. (1954). Trans R. Soc. Trop. Med. Hyg., 48, 400.

\section{Group I \\ Serum $A$}

Early and Late Reactions to Dharmendra's Antigen and Controls

\begin{tabular}{|c|c|c|c|c|c|c|c|}
\hline \multirow[b]{2}{*}{$\begin{array}{l}\text { Case } \\
\text { No. }\end{array}$} & \multicolumn{7}{|c|}{ (Dose of mixture injected 0.2 c.c.) } \\
\hline & & $\begin{array}{l}\text { Lepromin } \\
\text { with } \\
\text { Saline }\end{array}$ & $\begin{array}{c}\text { Lepromin } \\
\text { with } \\
\text { T. Serum }\end{array}$ & $\begin{array}{c}\text { Lepromin } \\
\text { with } \\
\text { L. Serum }\end{array}$ & $\begin{array}{l}\text { Lepromin } \\
\text { with } \\
\text { Saline }\end{array}$ & $\begin{array}{l}\text { Lepromin } \\
\text { with } \\
\text { T. Serum }\end{array}$ & $\begin{array}{l}\text { Lepromin } \\
\text { with } \\
\text { L. Serum }\end{array}$ \\
\hline I & $\cdots$ & $15 / 3$ & $20 / 3$ & $26 / 3 \frac{1}{2}$ & 2 & 2 & $2 \frac{1}{2}$ \\
\hline 2 & $\ldots$ & $22 / 3 \frac{1}{2}$ & $23 / 3 \frac{1}{2}$ & $27 / 7 \frac{1}{2}$ & 2 & 2 & $2 \frac{1}{2}$ \\
\hline 3 & $\cdots$ & $37 / 5$ & $33 / 4 \frac{1}{2}$ & $39 / 6$ & $3 \frac{1}{2}$ & 4 & 4 \\
\hline 4 & $\cdots$ & $28 / 6$ & $34 / 5$ & $38 / 8 \frac{1}{2}$ & $\begin{array}{c}3 \\
\text { Ulcer }\end{array}$ & $3 \frac{1}{8}$ & $\begin{array}{c}4 \\
\text { Ulcer }\end{array}$ \\
\hline 5 & $\cdots$ & $23 / 3 \frac{1}{2}$ & $34 / 7$ & $40 / 12$ & 2 & 3 & 4 \\
\hline 6 & $\ldots$ & $35 / 5 \frac{1}{8}$ & $37 / 6 \frac{1}{2}$ & $4 \mathrm{I} / \mathrm{I} 3 \frac{1}{2}$ & 4 & 4 & 5 \\
\hline
\end{tabular}




\begin{tabular}{cccccccc} 
Group II & Serum $A$ \\
\multicolumn{8}{c}{ Early and Late Reactions to Wade's Antigen and Controls } \\
(Dose of mixture injected 0.2 c.c.)
\end{tabular}

\section{Group III \\ Serum $B$}

\section{Early Reactions to Dharmendra's Antigen and Controls}

(Dose of mixture injected 0.1 c.c.)

\begin{tabular}{|c|c|c|c|c|c|c|c|c|}
\hline \multirow{2}{*}{$\begin{array}{l}\text { Case } \\
\text { No. }\end{array}$} & \multicolumn{2}{|c|}{$\begin{array}{l}\text { Lepromin }+ \\
\text { Saline }\end{array}$} & \multicolumn{2}{|c|}{$\begin{array}{l}\text { Lepromin }+ \\
\text { Lepromatous Serum }\end{array}$} & \multicolumn{2}{|c|}{$\begin{array}{l}\text { Lepromatous } \\
\text { Serum + Saline }\end{array}$} & \multicolumn{2}{|c|}{$\begin{array}{l}\text { Tuberculoid } \\
\text { Serum + Saline }\end{array}$} \\
\hline & $24 \mathrm{hrs}$. & & & $48 \mathrm{hrs}$. & $24 \mathrm{hrs}$. & $48 \mathrm{hrs}$. & $24 \mathrm{hrs}$. & $48 \mathrm{hrs}$. \\
\hline $\mathbf{I}$ & $16 / 2 \frac{1}{2}$ & $15 / 3$ & $13 / 2 \frac{1}{2}$ & $19 / 3$ & Slt EI & Nil & Slt EI & Nil \\
\hline 2 & $19 / 2 \frac{1}{2}$ & $17 / 2 \frac{1}{2}$ & $29 / 3$ & $28 / 2 \frac{1}{2}$ & $5 / 2$ & $6 / 0$ & $6 / 2$ & $6 / 0$ \\
\hline 3 & $21 / 3 \frac{1}{2}$ & I $9 / 3$ & $21 / 4 \frac{1}{2}$ & $20 / 3 \frac{1}{2}$ & $5 / 0$ & Slt EI & $5 / 0$ & Slt EI \\
\hline 4 & $28 / 4$ & $25 / 4$ & $22 / 4$ & $24 / 3 \frac{1}{2}$ & Slt EI & Nil & $8 / 2 \frac{1}{2}$ & $12 / 2 \frac{1}{2} *$ \\
\hline 5 & $18 / 3 \frac{1}{2}$ & $18 / 3$ & $24 / 5$ & I9/4 & Slt EI & Nil & Slt EI & Nil \\
\hline 6 & $15 / 2 \frac{1}{2}$ & $17 / 2 \frac{1}{2}$ & $24 / 3 \frac{1}{2}$ & $22 / 3$ & $5 / 2$ & $\mathrm{Nil}$ & Slt EI & Nil \\
\hline & & & & & $\begin{array}{l}\text { * This } \\
\text { reac } \\
\text { tures }\end{array}$ & $\begin{array}{l}\text { tion } \\
\text { with } \\
\text { e re }\end{array}$ & as & 110 \\
\hline
\end{tabular}

\section{Group IV \\ Serum $C$}

\section{Early Reactions to Dharmendra's Antigen and Controls}

(Dose of mixture injected 0.2 c.c.)

\begin{tabular}{|c|c|c|c|c|c|c|c|c|}
\hline \multirow{2}{*}{$\begin{array}{l}\text { Case } \\
\text { No. }\end{array}$} & \multicolumn{2}{|c|}{$\begin{array}{l}\text { Lepromin }+ \\
\text { Saline }\end{array}$} & \multicolumn{2}{|c|}{$\begin{array}{l}\text { Lepromin }+ \\
\text { Lepromatous Serum }\end{array}$} & \multicolumn{2}{|c|}{$\begin{array}{l}\text { Lepromatous } \\
\text { Serum + Saline }\end{array}$} & \multicolumn{2}{|c|}{$\begin{array}{l}\text { Tuberculoid } \\
\text { Serum + Saline }\end{array}$} \\
\hline & $24 \mathrm{hrs}$. & $48 \mathrm{hrs}$. & $24 \mathrm{hrs}$. & $48 \mathrm{hrs}$. & $24 \mathrm{hrs}$. & $48 \mathrm{hrs}$. & $24 \mathrm{hrs}$. & $48 \mathrm{hrs}$. \\
\hline 7 & $2 \mathrm{I} / 5$ & $16 / 3 \frac{1}{2}$ & $20 / 5$ & $19 / 4$ & $7 / 2 \frac{1}{2}$ & $\mathrm{Nil}$ & $7 / 2 \frac{1}{2}$ & Nil \\
\hline 8 & $\mathrm{I} 7 / 4$ & I6/4 & $25 / 5$ & $21 / 5$ & $14 / 3 \dagger$ & $16 / 3 \dagger$ & $6 / 2$ & Slt EI \\
\hline 9 & $22 / 5$ & $18 / 4 \frac{1}{2}$ & $30 / 6$ & $22 / 5 \frac{1}{2}$ & $8 / 2$ & Nil & $5 / 2 \frac{1}{2}$ & $\mathrm{Nil}$ \\
\hline IO & $33 / 10$ & $30 / 8$ & $30 / 6$ & $3^{8} / 4 \frac{1}{2}$ & $19 / 2^{*}$ & $22 / 2^{*}$ & $6 / 0$ & $\mathrm{Nil}$ \\
\hline II & $20 / 2$ & $19 / 2 \frac{1}{2}$ & $30 / 5$ & $23 / 3$ & Slt EI & $\mathrm{Nil}$ & Slt EI & Nil \\
\hline I 2 & $22 / 6$ & $21 / 6$ & $24 / 7$ & $28 / 6$ & $12 / 2 \frac{1}{2} *$ & $14 / 2 \frac{1}{2} *$ & Slt EI & Nil \\
\hline & & & & & $\dagger$ Reacti & read as & + & \\
\hline & & & & & $\begin{array}{l}\text { * Reactio } \\
\text { All the } \\
\text { saline }\end{array}$ & $\begin{array}{l}\text { read } \\
\text { ther } \\
\text { cture }\end{array}$ & $\begin{array}{l} \pm . \\
\text { ctions } \\
\text { d as }\end{array}$ & se \\
\hline
\end{tabular}

